\title{
HAK ASASI MANUSIA (HAM) \\ DALAM ISLAM
}

Oleh : Dahlia H. Mo'u

\begin{abstract}
ABSTRAK
Masalah Hak Asasi Manuisa(HAM) pada saat ini sudah ber-kembang sedemikian rupa. Mesikpun dalam pembi-caraan sehari-hari term 'HAM' sering diucapkan secara umum, tetapi dalam kenyataannya dapat diklasifikasikan da-lam berbagai bidang kehidupan. Oleh karena itu nilai-nilai HAM yang terdapat dalam setiap bidang kehidupan harus men-dapat perlindungan oleh hukum, me lalui penegakan hkum itu sendiri.

Pada sisi lain secara factual telah terbukti bahwa risalah Islam sej ak awalnya telah memasukkan aturan HAM dalam ajaran-ajaran dasarnya yang dapat ditemukan pada sumbersumber ajaran-nya. Islam mampu menyodorkan langkah-langkah implementatif actual HAM dan usaha-usaha preventif terhadap berbagai pe-langgaran yang dilakukan negara-negara tertentu. Dan sebenarnya ajaran Islam mampu menjawab isu-isu HAM masa kini atau akan datang. Tulisan ini akan melacak konsep HAM dalam Islam.
\end{abstract}

Kata Kunci: Al-Islam dan hak asasi

\section{PENDAHULUAN}

Agama Islam memerintahkan umat manusia untuk mengikuti bimbingan yang Maha Kuasa selama hidupnya. Seluruh bumi ini merupakan masjid tempat manusia harus bertindak dalam setiap aspek kehidupannya demi beribadat kapada-Nya. Tujuan eksistensi maunsia di dunia menurut Islam adalah semata-mata untuk beribadah, menghambahkan diri serta patuh kepada Allah SWT.

Dalam totalitas Islam kewajiban manusia kepada Allah mencakup juga kewajibannya kepada setiap individu yang lain. Maka secara paradoks hak-hak setiap individu itu di lindungi oleh segala kewajiban di bawah hukum Ilahi, sehagaimana suatu negara secara bersama-sama dengan rakyat harus tunduk pada hukum, yang berarti negara juga harus melindungi hak-hak individu.

Terkait dengan hal ini, maka hakhak setiap individu tidak berbeda antara satu dengan yang lain, hak seseorang untuk hidup tidak berarti boleh melanggar hak orang lain, apalagi 
merampasnya. Sehingga jika segala sesuatunya berjalan demikian, sebenarnya tidak ada masaalah yang timbul. Baru seseorang melanggar hak orang lain, maka timbullah apa yang dinamakan pelanggaran HAM. Dan HAM tersebut merupakan masalah umat manusia sepanjang sejarah.

Saat ini sering didengar (di baca) kata "Perjuangan Hak Asasi Manusia" Begitupun dari media massa, kita sering membaca tentang pelanggaran Hak Asasi Manusia, khususnya di Indonesia dan di negara-negara lain pada umumnya yang tentunya hal ini merupakan masalah yang harus dicarikan solusinya. Untuk itu melalui tulisan ini akan dikemuka-kan pandangan Islam tentang HAM.

\section{DEFINISI HAK ASASI MANUSIA DAN KONSEPNYA DALAM ISLAM}

Definisi HAM sampai saat ini belum ada yang baku, pengertian dan perkembangan tentang hak tersebut selalu berubah sesuai dengan dinamika dari manusia itu sendiri. Bila di lihat dari definisi yang ada, pada hakikatnya membicarakan hak-hak yang ada pada manusia sebagai makhluk hidup.

Berikut ini akan dikemukakan definisi yang di rumuskan oleh be-berapa ahli, yitu : A. Mansur Efendi memberikan definisi ; hak manusia adalah hak milik bersama umat manu-sia yang diberikan oleh Tuhan untuk selama hidupnya. ${ }^{2}$

Dad Darmodiharjo memberi-kan definisi ; Hak asasi manusia untuk dasar dan hak-hak pokok yang mem-bawa manusia semenjak lahir sebagai anugrah dari Tuhan Yang Maha Esa. $^{3}$

Sidney Hook, memberi defi-nisi; Hak asasi manusia adalah tuntut-an yang secara moral bisa dibenarkan, agar seluruh manusia dapat menikmati dan melaksa-nakan kebebasan dasar mereka harta benda dan pelayanan-pelayanan mereka yang dipandang perlu untuk mencapai hakikat manusia. ${ }^{4}$

Berdasarkan beberapa definisi para ahli tersebut, dapat dipahami bahwa HAM adalah berbagai fasilitas dasar yang diberikan oleh Tuhan kepada umat manusia, yang diantara sesama manusia tersebut memiliki fasilitas yang sama. Hanya pada level praktisnya, antara yang satu dengan yang lainnya akan ditemukan banyak perbedaan. Hal ini tergantung pada sejauh mana manusia itu sendiri mampu mengusahakan hak tersebut secara optimal. Misalnya manusia sama-sama mempunyai hak hidup pada kenyatannya kehidupan manusia 
itu ada yang hidupnya dapat memberi manfaat kepada orang lain, ada juga yang hidupnya justru membahayakan (merugikan) bagi orang lain. fiqih abad pertengahan. Dalam fiqih kategori haaq Al-Abd., hak individu muslim, kasus yang tindakan hukumnya terdapat pelanggaran diserahkan kepada kebijaksanaan pihak yang dirugikan, berbeda dengan kategori hak Tuhan, haaq Allah yang tindakan hukumnya harus dilakukan dengan perintah. Satu prinsip fiqih yang dapat disamakan dengan hak dalam penger-tian moderen adalah hak pemilik harta untuk mendapatkan bantuan hukum terhadap gangguan atas hartanya. ${ }^{5}$

Menurut Dr. Syekh Syaurat Hussain, terdapat dua macam HAM jika dilhat dari ketegori huquuqul' ibad yaitu Pertama : HAM yang keberadaanya dapat diselenggarakan oleh suatu negara

(Islam). Kedua : HAM yang keberadaannya tidak secara langsung dapat dilaksana-kan oleh suatu Negara.

Hak-hak pertama yang dapat disebut sebagai hak-hak legal, sedang yang kedua disebut sebagai hak-hak moral. Perbedaaan keduanya hanya ter-letak pada masalah pertanggung-jawaban didepan suatu negara Islam. Adapun dalam masalah sumber asal, filsafat dan pertanggungjawabannya dihadapan Allah SWT Yang Maha Kuasa itu sama. ${ }^{6}$

Aspek khas dalam konsep HAM Islam adalah tidak adanya orang lain yang dapat memaafkan suatu pelanggaran hakhak jika pelanggan itu terjadi atas seseorang yang harus dipenuhi haknya. Meskipun Allah sendiri telah menganugerahkan hak-hak ini, dan secara asalnya adalah tetap bagiNya. Serta didepanNyalah semua manusia wajib mempertanggungjawabkan, Allah tidak akan melaksanakan kekuasaanNya untuk mengampuni pelanggaran hak-hak pada hari akhirat kelak.

Secara universal, pada hakikat-nya misi Rasulullah itu sendiri adalah untuk menegakkan HAM. Beliau sebagai Rahmat Lil Alamin, dalam setiap kesem-patan selalu mendahulukan HAM sekali-gus KAM (Kewaj iban Hak Asasi Manusia). Keadilan sebagai ciri HAM adalah tuntunan jelas yang tercantum dalam Al Qur'an. ${ }^{7}$

Adapun Islam telah memberikan jaminan pada kebebasan manusia. Dalam Al Qur'an Allah menegaskan bahwa memeluk agama tidak dipaksakan, sebab telah jelas yang baik dan buruk itu. Demikian juga kebebasan berpendapat, Islam meletakkan kedudukannya pada posisi tinggi, bila berangkat dari niat suci semata karena Allah. Oleh karena itu banyak ayat- 
ayat Al Qur'an yang mendo-rong umat Islam agar menggunakan logika (ya'qiluun), berfikir (yatafakkaruun) dan berkontemplasi (yatadabbaruun).

Sampai abad ke-1 8 bangsa-bangsa di dunia masih meletakkan sekatsekat yang kokoh dalam

kelas dan kasta. Namun kehadiran Islam sejak lebih empat belas abad lampau telah menghilangkan dinding pemisah itu dengan semangat persamaan (egalitarianisme) sebelum bast melakukannya. 8

Dalam hal ini mnegenai persamaan tersebut, termaktub dalam QS. Al Hujarat (49) : 13, Yaitu

Artinya

"Hai sekalian manusia sesungguhnya kami menciptakan kamu dari seorang laki-laki dan seorang perempuan dan menjadikan kamu berbangsa-bangsa dan bersuku-suku supaya kamu saling kenal mengenal. Sesungguhnya orang yang paling mulia diantara kamu disisi Allah adalah yang paling bertaqwa diantara kamu. Sesungguhnya Allah Maha Menge- tahui lagi Maha Mengenal.'

Kemudian semasa kerasulan nabi Muhammad SAW yang bersamaan pula dengan para sahabat, membebaskan system perbudakan yang marak saat itu. Tanpa membedakan warna kulit, suku, ras maupun agama. Ajaran persamaan itu telah berhasil membentuk watak para sahabat nabi yang umumnya semula sangat feodal dan aristrokat, begitu tinggi men-junjung hak asasi manusia.

Dengan mengacu kepada landasan Yuridis diatas, dipahami bahwa pada dasarnya Islam, sejak awal telah mengedepankan konsep hak asasi manusia. Dan konsep HAM bukanlah hasil evaluasi apapun dari pemikiran manusia, namun merupakan hasil wahyu Ilahi yang telah diturunkan melalui RasulNya.

\section{UPAYAH PEMECAHAN MASALAH HAM}

Persoalan HAM saat ini muncul kepermukaan dengan menyita perhatian umat manusia. Kaum buruk menuntut hak-haknya, para tenaga kerja wanita menuntut hak-haknya pula dan rakyat pun menuntut hak-hak demokrasinya.

Jika dipahami kata 'hak' tidak bisa dibicarakan terpisah dari kewajiban, karena tidak akan ada hak tanpa kewajiban. Keduanya berjalan seimbang, dan keseimbangan inilah yang mewujud- kan keadilan. 
Salah satu prinsip Islam, menyebutkan bahwa semua kita adalah pemimpin yang akan dimintai pertanggungj awaban atas kepemirnpinan-nya. Pemimpin bertanggung jawab berlaku adil yaitu menjamin bahwa apa dan siapapun yang dipimpinnya akan mendapat semua haknya tanpa terkecuali. Dan karena semua orang adalah pemimpin, maka kewajiban menjamin hak-hak siapa saja. Dan ini adalah ajaran dasar tentang hak asasi manusia dan makhluk lainnya. ${ }^{9}$

Kemudian dalam prinsip al-amru bil ma'ruf wan nahyu ' anil munkar, jelas tergambar bahwa dalam rangka hidup berbangsa dan bernegara, tiap-tiap warga negara mempunyai hak untuk mendukung yang baik dan melakukan sosial kontrol terhadap yang tidak baik. Dalam hal ini tergambar bahwa Islam memerintah-kan umatnya untuk beriman, melarang keja-hatan dan memerintahkan kebajikan. Dengan memerintahkan kewajiban ini, Islam dapat menjadikan masya-rakat waspada terhadap negara atau kekuasaan asasi manusia dan makhluk lainnya. ${ }^{9}$

Kemudian dalam prinsip al-amru bil ma'ruf wan nahyu ' anil munkar, jelas tergambar bahwa dalam rangka hidup berbangsa dan bernegara, tiap-tiap warga negara mempunyai hak untuk mendukung yang baik dan melakukan sosial kontrol terhadap yang tidak baik. Dalam hal ini tergambar bahwa Islam memerintah-kan umatnya untuk beriman, melarang keja-hatan dan memerintahkan kebajikan. Dengan memerintahkan kewajiban ini, Islam dapat menjadikan masya-rakat waspada terhadap negara atau kekuasaan yang melanggar batasan.

Pemikiran filsafat telah banyak memberi petunjuk kepada manusia ten-tang bagaimana hubungan sese-orang dengan orang lain, antara seorang warga negara dengan pe-merintah dan sebalik-nya. Akan tetapi dalam praktek kehidupan sehari hari sering terjadi perbedaan dan bahkan pertentangan dengan ajaran-ajaran filsafatnya sendiri.

Dalam situasi ini, diperlukan jaminan hukum. Hak-hak seorang warga negara terhadap negaranya harus dijamin secara timbal balik. Dan diberikan persamaan hak untuk membicarakan masalah-masalah bersama. Tidak ada hak monopoli bagi suatu golongan dalam menangani masalah-masalah bersama. Bahkan hal ini hams juga meliputi hak-hak untuk berpartisipasi. Karena dengan member-lakukan hak berpartisipasi itu akan lebih mendekatkan orang kepada tanggung jawabnya terhadap kehidup-an bersama. 
Jika dilihat dari hasil deklarasi HAM Islam sedunia, dimana deklarasi ini berdasarkan kitab Al-Qur'an dan Hadits. Sangatlah tepat jika hal ini dijadikan upaya pemecahan masalah, yang sampai saat ini masih dirasakan umat manusia.

Dalam deklarasi HAM tersebut, terdapat komitmen bersama untuk menegakkan HAM, yaitu meliputi

1. Hak hidup

2. Hak Kemerdekaan

3. Hak persamaan dan larangan terhadap adanya diskriminasi yang tidak terizinkan.

4. Hak mendapatkan keadilan

5. Hak mendapatkan proses hukum yang adil

6. flak untuk mendapatkan perlindungan dari penyalahgunaan kekuasaan.

7. Hak untuk mendapatkan perlindungan dari penyiksaan.

8. Hak untuk mendapatkan perlindungan atau kehormatan dan nama baik.

9. Hak untuk memperoleh suaka

10. Hak-hak yang minoritas.

11. Hak dan kewajiban untuk berpartisipasi dalam pelaksanaan dan urusan- urusan publik.

12. Hak kebebasan percaya, berfikir dan berbicara.

13. Hak kebebasan beragama.

14. Hak berserikat bebas.

15. Susunan ekonomi dan hak berkembang darinya.

16. Hak memperoleh perlindungan atas harta benda.

17. Status dan martabat pekerja dan buruh.

18. Hak membentuk suatu keluarga dan masalah-masalahnya.

19. Hak-hak wanita yang sudah menikah.

20. Hak mendapatkan pendidikan.

21. Hak menikmati keleluasaan pribadi.

22. Hak mendapatkan kebebasan ber pindah dan bertempat tinggal. Io

Berdasarkan deklarasi HAM diatas, dipahami bahwa HAM dalam Islam bertujuan mengarahkan. Martabat dan kehormatan bagi umat manusia, serta dicanangkan untuk 
menghapus segala penindasan dan tidak adilan. Olehnya itu upaya pe-mahaman (interpretasi) yang baik terhadap nilai-nilai persamaan dan keadilan dalam Al-Qur'an maupun hadits, perlu ditingkatkan bahwa diaplikasikan dalam situasi sekarang.

- Dalam hal ini terdapat beberapa usaha perlindungan dalam Islam terhadap pelaksanaan HAM yaitu Adanya konsep kedaulatan Allah, dimana umat Islam ataupun seluruh umat manusia dianggap sebagai warga negara dari sang penguasa yang sebenarnya. Tak ada seorang pun yang mempunyai superioritas diatas lainnya. Manusia dilarang melakukan tindakan pelanggaran HAM.

- Manusia diangggap sebagai Khali-fah, dimana dengan amanah ke-khalifahan manusia harus melakukan aktifitasnya sesuai dengan hukum yang telah ditetapkan Allah SWT.

- Adanya konsep kesucian hak-hak manusia karena Al-Qur'an menyata-kan bahwa barang siapa membunuh seorang anak manusia, maka seakan- akan is telah membunuh seluruh manusia.

- Pendidikan masyarakat yakni dengan mengadakan pendidikan masyarakat yang berkaitan dengan hak-hak dan kewajibannya. Dan pendidikan meru-pakan jaminan yang nyata terhadap HAM.

Dengan melihat uraian di atas, bahwa dengan melaksanakan ajaran Islam tentnag HAM, maka segala upaya yang merugikan akan lenyap bahkan melanggar HAM tidak akan pernah terjadi.

\section{PENUTUP}

Berdasarkan uraian pembahasan dapat disimpulkan : Hak asasi manusia dalam pelaksanaannya telah ada sejak adanya Islam, karena prinsip-prinsip HAM sudah tertuang kedalam Al-Qur'an dan Hadits Muhammad SAW.

Bahwa hal-hal yang fundamental dan kebebasan-kebebasan universal dalam Islam adalah suatu bagian yang integral dari agama Islam itu sendiri. Untuk melindungi dan menegakkan HAM, harus berdasarkan hukum yang jelas dan adil, menegakkan perlindungan HAM akan lebih terjamin. 


\section{CATATAN KAKI}

1. Lihat Qur'an Surat: Al-azhab (6) ayat 162-163

2. Mansur Efendi, Tempat Hak Asasi Manusia dalam Hukum Nasional/Internasional (Bandung Alumni 1980), h.20

3. Darmaji Darmodiharjo, Pendidikan Pancasila diperguruan Tinggi, (Malang Laboratorium Pancasila IKIP, 1989), h.25

4. Sidney Hook et.al, Hak Asasi Manusia Dalam Islam, penyunting Harun Nasution dan Bahtiar Effendy, (Jakarta ; Pustaka Firdaus, 1995), h. 19

5. Lihat Jhon. L. Eposito, Ensiklopedi Oxford Dunia Islam Modern (Jilid II cet I ; Bandung : Mizan, Zoon). H. 136

6. Lihat, Syekh Syaukat Hussain, Hak Asasi Manusia Dalam Islam, Diterjemahkan oleh Abdul Rochim C. H, (Cet. I ; Jakarta Gema Insani Press, 1996), h.55

7. Lihat QS. An -Nisaa (4) : 58. Departemen Agama RI, Al terjemahannya, (Surabaya: Mahkota 1989), h.

8. Lihat, Anwar Harjono, Indonesia Kita Pemikiran Berwawasan Iman - Islam, (Cet. I ; Jakarta Gema Insani Press, 1995),h. 11.

9. Lihat, Syekh Syaukat Hussain, Op. cit, hal.144 